\title{
INFORMACIONES
}

\section{CONGRESO NACIONAL DE FILOSOFÍA MEDIEVAL}

Abundan, ciertamente, los congresos. No en vano representan el modo y lugar apropiados para compartir y discutir conocimientos adquiridos, así como para avanzar conjuntamente en nuevas propuestas de investigación. Pero no abundan, y menos en nuestro territorio nacional, los congresos en torno al tan complejo, y a la vez, fructífero periodo medieval de pensamiento. Es por ello digno de aplaudir la celebración del II Congreso Nacional de Filosofía Medieval, que tuvo lugar, en intensas sesiones de trabajo, los días 15 y 16 de diciembre de 1994 en la sede de Ibercaja, sita en Zaragoza.

A la Sociedad Española de Filosofía Medieval y principalmente a su presidente y secretario, corresponde el esfuerzo y el mérito de haber organizado tal encuentro. Le corresponde también el haber acertado plenamente en la temática propuesta a la reflexión: Ética y Política en el Pensamiento Medieval. Fundamentos de la Modernidad. La, afortunadamente, cada vez menos denostada época medieval revela su mejor vía de asunción en el reconocimiento de que sin ella nuestra Modernidad, para bien y para mal, no podría ser lo que es.

A los dos centenares largos de participantes en el Congreso, lo cual avalaría su éxito cuantitativo, hay que sumar la calidad innegable de los ponentes y de sus ponencias. Es imposible, por fuerza, hacer justicia a dichos ponentes en una breve, o incluso larga, reseña. Conscientes, por tanto, de nuestra limitación, vamos sólo a indicar las cuestiones más relevantes y novedosas, de entre las muchas tratadas.

Se abrieron las sesiones de trabajo con la ponencia que sobre Ética, Derecho y Política en la Alta Edad Media, ofreció el Dr. D. Jesús Morales de la Universidad de Pamplona. Quiso el ponente resaltar los mecanismos de incorporación de reglas éticas en el sistema jurídico, reivindicando la figura de un pensador nacional cuasi desconocido e infravalorado: san Isidoro de Sevilla. En la segunda mitad del siglo VII, Isidoro, recogiendo la tradición proveniente de Séneca, Cicerón, Gregorio Magno y, principalmente, San Agustín, consigue incorporar el sistema de reglas de la moral cristiana al poder civil, a través de la noción capital de directum o derecho. En él, la figura del rey adquiere relevancia fundamental, pero el ejercicio de su poder queda corregido por una ley moral que deriva del ámbito religioso. La Edad Media no pasó, por tanto, en balde por lo que se refiere a la configuración actual 
de la esfera jurídica. La necesidad actualmente sentida de un control ético del ejercicio político y jurídico fue magníficamente vista por la Alta Edad Media.

A continuación el Dr. D. Ramiro Flórez disertó sobre Los presupuestos del Agustinismo Político Medieval. El catedrático de la Universidad Autónoma de Madrid indicó, desde el inicio, su intención de plantear problemas más que de aventurar difíciles y controvertidas respuestas a los mismos. Alertó, también, de un peligro actual de indudable importancia, a saber: los fundamentalismos de tipo religioso. Centrándose en el De Civitate Dei, el ponente aludió a la complejidad de la obra y a la ausencia de una terminología segura y definitiva, lo cual introduce una ambigüedad fundamental. Controvertidas son igualmente las denominadas «Ciudad de Dios» y «Ciudad terrena». Representan no tanto realidades históricas temporalmente identificables, cuanto símbolos que, si bien podrían contrastarse empíricamente, remiten a algo no presente y siempre actuante. Finalmente, aunque el transfondo religioso y transcendente agustiniano es insuperable, no habría ni una condenación de todo poder civil ni una desaparición del mismo en el poder eclesiástico. Ello manifiesta lo complejo de las relaciones entre los dos poderes.

El catedrático de la Universidadd de Valencia, Dr. D. Jesús Montoya, presentó su ponencia titulada Pedro Abelardo y el descubrimiento del individuo en el siglo XII. La ruptura del transfondo armónico, típicamente aristotélico, entre la perfección del hombre y los valores de la polis, tuvo lugar en el siglo XII con el descubrimiento abelardiano del individuo y de su libérrima intención, como criterio único de valoración moral. La primacía de la buena voluntad, la separación entre moral individual y social y el heroísmo solitario, que se encarna en la libertad total del hombre, son rasgos típicamente abelardianos, que reaparecerán en la modernidad kantiana y sartriana.

El Dr. Eudaldo Forment, catedrático de la Universidad de Barcelona, reflexionó sobre La integración de la ética aristotélica en la sintesis escolástica. Es, efectivamente, santo Tomás de Aquino el que consigue la integración completa de la ética aristotélica en el escolasticismo, en una triple dimensión: a) asunción completa y no modificada de conceptos aristotélicos, tales como virtud, justo medio, prudencia, recta razón y papel de las pasiones; b) desarrollo de ciertos componentes en una línea teologal, tales como el placer sensible y el elemento material del hombre; c) introducción de realidades ajenas al aristotelismo, tomadas de la tradición patrística, como la ley natural, la gracia, la humildad, la caridad y la contemplación amorosa como fin último. Nuestro conocimento de Aristóteles pasa inevitablemente por la interpretación cristiana de santo Tomás.

Los orígenes del espíritu laico, fue la ponencia presentada por el catedrático de la Universidad de Navarra Dr. D. Josep Ignasi Saranyana. Centró su reflexión en las relaciones establecidas entre el poder espiritual y el temporal desde la Epístola VIII del papa Gelasio (siglo I), hasta la polémica surgida en $1260-1265$ en torno al aristotelismo parisino heterodoxo. En este largo periodo, las relaciones transitan desde la doctrina güelfa, que afirma la superioridad, perfección y primacía del poder papal, hasta la gibelina, que opta por la autonomía del poder temporal del emperador. En la duda queda la razón de por qué santo 
Tomás no acabó su opúsculo De Regno. El ponente aventuró que, quizá, santo Tomás, vislumbrando la fuerte querella doctrinal que se avecinaba en París, prefirió no intervenir en favor de un aristotelismo político que, en manos de la interpretación averroísta, aparecía como herético.

El turno de ponencias quedó cerrado por el catedrático de la Universidad de Salamanca, Dr. D. José María G. Gómez-Heras. La disertación sobre Prerreforma y modernidad, giró en torno a las figuras ockhamista y kantiana, como ejes paradigmáticos de la premodernidad y modernidad, respectivamente. Discrepando acerca del sujeto último de la libertad, Dios para Ockham, el hombre para Kant, mantienen una profunda coincidencia de base, al señalar la libertad, la capacidad autolegisladora, la autonomía y la autodeterminación en cuanto criterios decisivos del hecho moral. Si Ockham ensaya un nuevo sistema moral, mediante el rechazo del naturalismo determinante aristotélico, Kant establece el suyo a través de la crítica al naturalismo utilitarista anglosajón. La idea capital de la modernidad, que descansa en la libertad autolegisladora, vendría a ser una reproducción de la forma mental ockhamista, secularizada antropocéntricamente.

Cada ponencia fue seguida de debates, no sólo interesantes, sino reveladores de las múltiples posibilidades interpretativas.

El Congreso se completó con la lectura de numerosas comunicaciones y con la celebración, en dos sesiones, de un peculiar y muy sugerente seminario tiulado Comentario de textos e informática. Ópera política de Guillermo de Ockham, ofrecido por el catedrático de la Universidad de Barcelona Dr. D. Francisco Fortuny.

Es de esperar que la celebración de posteriores congresos continúe enseñándonos a valorar y recuperar el todavía inagotado trasfondo medieval.

Begoña Arrieta

\section{FRANCISCO DA GAMA CAEIRO 26-V-1928/18-IX-1994}

Cuando se encontraba en plena preparación del Congreso Internacional sobre el VIII Centenario del Nacimiento de San Antonio de Padua, que tendrá lugar durante los días 2530 de septiembre de 1995, falleció inesperadamente nuestro buen amigo el Doctor Francisco da Gama Caeiro, prestigioso medievalista portugués. El año pasado hicimos en esta misma revista una reseña del libro que le dedicaron sus amigos y discípulos con motivo de su jubilación como profesor de la Facultad de Letras de la Universidad de Lisboa. El título del libro es: Pensar a Cultura Portuguesa. Homenagem a Francisco da Gama Caeiro, Lisboa, 1993. En Crítica de libros podrán leer nuestros lectores una reseña sobre el último libro que nos mandó a esta redacción, y que es una monumental obra dedicada a las universidades portuguesas. El Doctor Francisco da Gama Caeiro era muy conocido en los ambientes filosóficos españoles por su asistencia a congresos y simposios. Descanse en paz. 